\title{
Implanting Morals in The Implementation of the Distance Learning System
}

\author{
${ }^{*}$ Ano Maryano ${ }^{1}$, Slamat Sholeh ${ }^{2}$ \\ ${ }^{1,2}$ (Universitas Singaperbangsa Karawang, Jl. HS.Ronggo Waluyo, \\ Puseurjaya, Karawang, Indonesia) \\ *maryanoano79@gmail.com
}

\begin{abstract}
This research aims to describe the efforts of classroom teachers in the cultivation of noble morals through religious activities in students of class V Madrasah Ibtidaiyah Nurul Islam Jatisari District karawang. This research uses a qualitative approach that intends to understand what phenomena are experienced by the research subject. Data collection uses observation, interview, and documentation methods. The results showed that the efforts made by teachers in the cultivation of noble morals in students through religious activities in students of class V Madrasah Ibtidaiyah Nurul Islam Jatisari District karawang are through routine activities such as performing congregational dhuha prayers, congregational dhuhur prayers, tahfiz juz 30 programs, and muhadharah programs. From the everyday activities supported by the facilities and infrastructure, the cooperation of the school with the parents of students. The problem of routine activities is limited time, lack of parental attention to the development of student character, and the impact of the surrounding environment.
\end{abstract}

Keywords: Planting Morals, Implementation, Distance Learning System.

\section{Introduction}

The Covid-19 pandemic has compelled us all to alter, even Islamic instructors and educational institutions. The learning process, which is usually on-campus face-to-face, must now be done online. However, the principle of education must convey three aspects, namely cognitive, psychomotor and affective. Not all can run optimally. "Cognitive (knowledge) and psychomotor elements (skills) can be done online. Teachers provide teaching materials or materials online. However, in the field of affective to learners, not all finished with online learning (Syukur, 2020).

In 2020, in line with the importance of character education, children finally encountered problems in Indonesia and worldwide. 
The global situation is in the form of transmission of viruses that are harmful to health and safety and can infect various circles across the age range, indiscriminately the age of toddlers or adults.

Initially, the disease was provisionally named the 2019 novel coronavirus, then WHO announced a new name on February 11, 2020, namely Coronavirus Disease (Covid-19) caused by severe acute respiratory syndrome coronavirus-2 (SARS-CoV2). The virus can be transmitted from human to human and has spread widely in China and more than 190 other countries, including Indonesia. On March 12, 2020, WHO declared Covid-19 a pandemic. (Adityo Susilo et al.2019). The covid-19 pandemic has led to the closure of schools and public places, no activity except staying at home to break the chain of the spread of covid-19.

Covid-19 was first reported in Indonesia on March 2, 2020, at which time there were two cases. (Adityo Susilo et al., 2019). The government makes various regulations to deal with and overcome the covid-19 pandemic, such as regulations: (1) stay at home; (2) social restrictions (social distancing); (3) physical distancing; (4) the use of protective equipment (masks); (5) maintaining personal hygiene (handwashing); (6) work and study at home; (7) postpone all activities that gather crowds; (8) large-scale social restrictions (PSBB); until last, (9) the enactment of the New Normal policy.

As the end of the implementation of the government regulation, all community activities are mainly activities to meet with fellow humans "face to face", which is the interaction between humans with humans, which initially all carried out directly outside the home or meet in person, but because of covid-19, all human activities be it factory activities, industrial activities, business activities, educational activities, office activities, social activities, cultural activities, sports activities, political activities, to religious activities, all prohibited and should only be done at home (Tuwu, 2020).

The cultivation of noble morals emphasized in learning activities in schools should be carried out continuously in the implementation of distance learning. The basic principle of developing moral cultivation cannot simply arise but proceeds from a constantly constructed environment (Sunaryo, Sendayu, \& Syam, 2021). The cultivation of noble morals can be formed and conditioned by a person. Teachers in school and parents can prepare it at home and in a community environment (Winaya, 2020). 
Distance learning is not easy to do. Distance learning is very different from face to face learning. In school, character education has been strengthened well, namely by slipping the planting of noble morals in every learning activity (Ikhwan, Anwar, \& Mahmudah, 2021). With the covid-19 pandemic, teachers must be good at packaging learning and declining character education values when using distance learning. Institutions, especially in MIS Nurul Islam, use distance learning methods to conduct learning in the covid-19 period. This method is felt right during this hazardous outbreak. The results of interviews with teachers about the learning system shown at MIS Nurul Islam during this pandemic experienced problems that teachers have difficulty conditioning students during distance learning. Distance learning allows children to be lazy to do tasks.

The impact makes the child not collect tasks or underestimate the tasks given by the teacher. While the researchers' interviews with students revealed that they did not know the answer to the math problem because his mother did the math problem, and his mother did not teach the way or solution to the math problem.

From this, it is seen that the child does not have the independence to do homework given by his teacher, and the child is also not responsible for the tasks assigned by the teacher. Researchers take the theme of independent character and student responsibility because the problems that are happening are that students are not independent doing homework given by teachers, their parents do the task.

While the character of responsibility is seen when the child does not have a sense of responsibility towards his pr, researchers chose the research location in MIS Nurul Islam because of the school's strategic location, close to the highway, easy to reach. In addition, researchers found related problems in the background. Researchers focused on class V MIS Nurul Islam because class V already includes high class instead of low class anymore such as grades 1, 2, and 3. Researchers feel that class $\mathrm{V}$ should have matured to understand the task given by the teacher, already had to do his job, but here in class $\mathrm{V}$, there are still students who are not independent and responsible for doing their homework.

In the Qur'an itself, many describe the cultivation of noble morals that start from the family as stated in Surah Al-Luqman verse 13, which reads:

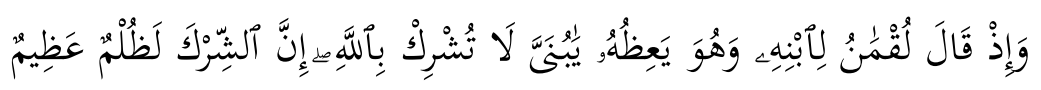


"And (remember) when Luqman said to his son, when he taught him, O my son! Do not associate with Allah, but it is a great injustice". QS. Luqman: 13).

In the above verse, it is explained that the most emphasized education is the cultivation of noble morals carried out by parents to their children and starting from their own families because education from parents is the first education obtained by a child before getting an education from outside such as school or madrassa (Aqil, 2018). Then the verse explains that parents, as their first teacher's children, must teach about the prohibition of doing things that are not by the teachings of Islam (Ridwan \& Ikhwan, 2021).

In addition, the following verse explains the basic principles of solid character education material consisting of matters of faith, worship, social, and science that will later shape the character of a child to become the provision of his future (Ramadhona, 2021).

According to neurobehavior, ages $7-12$ is the golden period, during which the basis of human behaviour is being formed. It turns out that human behaviour is very dependent on the work of the brain called the frontal and parietal lobes. Behaviour is based on memory systems recorded in the human brain. If the memory is recorded well, then the behaviour will be good.

Vice versa, if the recorded memory is terrible, then the behaviour will tend to be wrong. As already explained that human behaviour is very dependent on brain performance. Therefore, character formation can begin from early childhood to form the child's character quickly. Through habituation, know which behaviours or actions are good and evil, which can be done which ones are not expected to be a child's habit (Efendi \& Ningsih, 2020).

Some literature studies that have discussed the cultivation of implementation morals is the Learning of Islamic Religious Education in the Cultivation of Character Education Values in Learners at SDN Inklusi Klampis Ngasem 1 Surabaya. This study focuses more on the importance of Islamic religious lessons in cultivating character education in students. Students in SDN are a mixture of regular students and students with special needs.

The cultivation of noble morals should be applied from the basis of the age of children or commonly referred to by psychologists as the golden age because the period proved to be very decisive whether the child's ability to develop his potential. But in some families, perhaps the process of systematic or structured character education above is 
complicated, especially for some parents stuck in a hectic routine (Anwar, 2021). Character education should also be provided when children enter school, especially in playgroups and kindergartens. And it should be maximized at the age of MI. Since birth, humans have owned good potential, but the possibility must still be fostered and developed from family, school, and community (Efendi \& Ningsih, 2020).

This is where the role of teachers, which in Javanese philosophy is called digugu can ditiru, is at stake because the teacher is the spearhead in the classroom, which is directly dealing with learners (Annisa, Wiliah, \& Rahmawati, 2020).

\section{Method}

This study uses a qualitative approach that intends to understand what phenomena are experienced by the research subjects. Collecting data using the method of observation, interviews, and documentation. Data analysis using statistical tests by testing the independent and dependent variables about the cultivation of noble character in students in applying the distance learning system at MIS Nurul Islam (Ikhwan, 2021).

\section{Result and Discussion}

The results showed that the efforts made by the teacher in teaching noble character in students through religious activities in class V Madrasah Ibtidaiyah Nurul Islam, Jatisari Karawang District were through routine activities such as carrying out dhuha prayers in congregation, dhuhur prayers in congregation, tahfiz juz 30 programs, and muhadharah programs. They started from regular activities supported by facilities and infrastructure and school collaboration with parents. Problems with routine activities are limited time, lack of parental attention to student character development, and the impact of the surrounding environment.

\section{Planting of Noble Morals in MI Nurul Islam}

The cultivation of solid and noble morals is usually formed by cultivating noble moral education values in MI Nurul Islam, which emphasizes good and bad deeds. Planting this value can be built through the process of imagination and experience through which and the process of generating feelings. Want and occupy yourself with helpful knowledge. 
According to Ammis Matta in his book entitled Forming the noble morals of Muslims, he mentioned several rules about the process of forming noble moral, educational values, namely:

1. The rules of godliness are a process of change, improvement, and development that is carried out gradually. A person, in this case, can not be required to. Change as desired instantly or suddenly, but it must go through several stages. That is patient and not rushed.

2. The rule of continuity, which is an exercise. That must be done. Continuously. No matter how small the portion of practice done will not be a problem during the training. Because a constantly done process can form a sense and colour of a person's thinking that will later become a distinctive and robust character.

3. The rule of momentum is a process that uses an event for functions: education and training. For example, it is using the moment of the fasting month of Ramadan to float or cultivate patience, willpower, generosity towards others, and other good deeds.

4. The rule of intrinsic motivation is a process of solid and perfect character formation that is driven or motivated by self-desire, not because of influence or coercion from others.

5. The guiding rule is a process of help from others to achieve a better result than one does itself. The formation of the character of this guiding rule cannot be done without a guide or teacher (Matta, 2003).

Sources of Planting Values of Noble Moral Education in MI Nurul Islam Values which can be developed in MI Nurul Islam in the cultivation of noble moral planting values obtained from the source below:

\section{Religion}

Indonesian society is a society that holds firm religion. Therefore, an individual's life, a group of people, and the State must be based on religious beliefs and beliefs. State life is based on values derived from religion. On that basis, the educational values of the character and culture of the nation must be found on the importance and rules derived from religion.

2. Pancasila 
The Indonesian state applies the principles of national and state life called Pancasila. Education karakter and the nation's culture aim to prepare better learners, as citizens who have the will, ability, and apply the values of Pancasila in everyday life.

\section{Culture}

Cultural values are used as a guideline and basis in giving meaning to a concept in communication between members of society. Culture has a critical position in community life that requires community life to be a source of value in character education.

4. National educational objectives

This national education aims to contain various units of teaching at multiple levels and pathways that Indonesian citizens must own. Therefore, national education is the most crucial source in developing the nation's character and cultural education. Stages of Planting Noble Moral Education Values in MI Nurul Islam. The values of noble moral education can be divided into several stages, namely:

\section{Stage.adab (age 5-6 years)}

At the age of 5-6 years, children are taught to know right or wrong values and taught to know a good or bad character. Children are also trained to know what to do and leave behind. Children are introduced to their creator through the teachings embraced, invited to imitate the worship movement, and accustomed children to be kind and polite (Permendikbud, 2009).

\section{Stages of responsibility (ages 7-8 years)}

In a hadith, it has been explained that when the child is seven years old, the child must be encouraged to perform the worship that has been ordered. This means that when the child is seven years old, the child must be accustomed to having the responsibility to carry out their obligations and duties, such as eating, bathing, and wearing clothes they must do independently.

\section{Stage caring (ages 9-10 years)}

When the child is seven years old, the child already knows the duties and responsibilities that they must do to themselves, but when the child is $9-10$ years old, the child must be taught to have a sense of care for others. Children should also be introduced to respect the rights and obligations of others and help others.

4. Stages of independence (ages 11-12 years) 
Moral education that children have obtained at a previous age can make children more mature and mature the character of children so that they can grow as independent children. Independence.ini is characterized by an attitude of willingness to accept the consequences and risks of all his actions and begins to distinguish what is right and what is wrong.

\section{Stages of community (age 13 years and above)}

At this stage, the child can live alive with the broader community. At this age, children must begin to be taught to have integrity and the ability to adapt to various types of society. Their experience at an earlier stage is expected to make their lives more colourful and implemented in community life.

\section{Conclusion}

From the discussion in the previous chapter, the researchers can conclude that: Problematika Planting Akhlak Mulia On Learners In The Implementation of Distance Learning System in MIS Nurul Islam Jatisari District Karawang In the form of; Delays in students in following online learning. Here, the delay of learners is influenced by various factors, including the control of parents, the facilities used by learners, and the motivation of the learners themselves. The second is that learners play games/chats while online learning occurs. As online learning progresses, learners play games while the teacher explains the material. The third problem is, educators cannot directly monitor learners in online education. When learning takes place remotely, educators have difficulty supervising learners directly. Fourth, learners commit fraud while doing assignments/exams. The last problem felt by educators is, learners do not try to know more about the material in distance learning.

Solutions related to The Problem of Planting Akhlak Mulia on Learners in the Implementation of Distance Learning System in MIS Nurul Islam Jatisari District Karawang Regency: Educators use daily journals given to students to control their activities, and educators use the internet and video in providing material to students. The third solution is that educators provide facilities to students to be contacted to explain other material that students lack understanding. The fourth solution is, educators offer different problems to each student (problem variations). The final solution is for educators to do a home visit to students who do not follow online learning. 


\section{Bibliography}

Annisa, M. N., Wiliah, A., \& Rahmawati, N. (2020). Pentingnya Pendidikan Karakter pada Anak Sekolah Dasar di Zaman Serba Digital. Jurnal Pendidikan Sains, 2(1), 36.

Anwar, S. (2021). Pendidikan Karakter: Kajian Perspektif Tafsir fi Zilalil Qur'an. Tulungagung: STAI Muhammadiyah Tulungagung.

Aqil, D. I. (2018). Building Religious Characters Through a Biological Perspective. Al-Hayat: Journal of Islamic Education (AJIE), 2(2), 167-176.

Efendi, R., \& Ningsih, A. R. (2020). Pendidikan Karakter di Sekolah. Pasuruan: CV. Penerbit Qiara Media.

Ikhwan, A. (2021). Metode Penelitian Dasar (Mengenal Model Penelitian dan Sistematikanya). Tulungagung: STAI Muhammadiyah Tulungagung.

Ikhwan, A., Anwar, S., \& Mahmudah, N. (2021). Tahsin and Tahfidz Learning System at Integrated Islamic Elementary School (SDIT) Insan Madani During the Pandemic Covid-19. Al-Hayat: Journal of Islamic Education (AJIE), 5(1), 1-11.

Matta, M. A. (2003). Membentuk Karakter Cara Islami. Jakarta: AlI'tishom Cahaya Umat.

Permendikbud. Peraturan Menteri Pendidikan Nasional Republik Indonesia No. 58 Tahun 2009 Tentang Standar Pendidikan Anak Usia Dini. , (2009).

Ramadhona, C. (2021). Penguatan Pendidikan Karakter Melalui Pjj Di Masa Pandemi. Retrieved from STIT Al-Kifayah Riau website: www.stit-alkifayahriau.ac.id

Ridwan, Y., \& Ikhwan, A. (2021). Education of Religious Characters in Indonesia. 2nd Annual Conference on Blended Learning, Educational Technology and Innovation (ACBLETI 2020), 435-440. Atlantis Press.

Sunaryo, S. A., Sendayu, F. S., \& Syam, A. R. (2021). Internalization of Huma Betang Cultural Values through Narrative Counseling for Elementary Education Students. JURNAL INDRIA (Jurnal Ilmiah Pendidikan Prasekolah Dan Sekolah Awal), 6(1).

Syukur, F. (2020). Penting Menanamkan Nilai Akhlak Dalam Pembelajaran Secara Online. Retrieved from Bisnis News website:

https://www.bisnisnews.id/detail/berita/penting- 
menanamkan-nilai-akhlak-dalam-pembelajaran-secara-online

Tuwu, D. (2020). Kebijakan Pemerintah dalam Penanganan Pandemi Covid-19. Journal Publicuho, 3(1), 71-72.

Winaya. (2020). Pengembangan Nilai-Nilai Karakter Anak Pada Pembelajaran Jarak Jauh Di Masa Pademi Covid-19 Dengan Berbantu Lembar Keja Siswa Berbasis Proyek. Jurnal Pendidikan Kewarganegaraan Undiksha, 8(1), 237. 